\title{
A checklist to avoid pilot failures: lessons from a program of pilots on women's economic empowerment initiatives
}

Sara Johansson de Silva ${ }^{\mathrm{a}}$, Pierella Paci ${ }^{\mathrm{b}}$, and Josefina Posadas ${ }^{\mathrm{c} 1}$

${ }^{a}$ World Bank, Malmö, Sweden; ${ }^{\mathrm{b}}$ World Bank, Washington, USA; ${ }^{\mathrm{c}}$ World Bank, Washington, USA.

\begin{abstract}
Pilot programs have gained significance in donor-supported development instruments because of the growing emphasis on measuring impact. The ResultsBased Initiatives (RBI) were conceived as pioneering pilots expected to acquire rigorous evidence on effective interventions to foster women's economic empowerment. However, they fell short of providing clear or generalizable conclusions on women's economic empowerment due to design and implementation problems. The RBI nevertheless offer important lessons on common traps in pilot design and implementation. This paper synthesizes ten lessons from the RBI as a checklist to avoid pilot failure, intended for practitioners in any area of development.
\end{abstract}

Key words: pilots, impact evaluation, entrepreneurship, training, skills, women, economic empowerment.

${ }^{1}$ Corresponding author: jposadas@worldbank.org 


\section{Acknowledgements}

This paper draws on the experiences, results, and lessons learned from the implementation of the Results-Based Initiatives (RBI). The RBI were among the first projects designed as part of the Gender Action Plan (GAP). The RBI in the Arab Republic of Egypt, Kenya, Liberia, Mekong, and Peru were funded by a Development Grant Facility grant to the United Nations Women and the International Center for Research on Women (ICRW). UN Women (then called UNIFEM) was responsible for the design and implementation of these RBI, while ICRW was responsible for the impact evaluations; the Bank had an overall supervisory role. Mayra Buvinic, Lucia Fort, Andrew Morrison, and Waafas Ofosu-Amaah from the World Bank conceived the initiative while developing the Gender Action Plan. Involved in the implementation of the Development Grant were Waafas Ofosu-Amaah (World Bank), Hiska Reyes (World Bank), Joanne Sandler (UNIFEM), Letty Chiwara (UNIFEM), Caroline Horekens (UNIFEM), Anne Golla (ICRW), and Anju Malhortra (ICRW). Several persons from the three organizations were involved in each of the pilots: Lorena Barba (UNIFEM; Peru), Helene Carlsson Rex (World Bank; Mekong), Carmela Chung (UNIFEM; Peru), Maria Elizabeth Dasso (World Bank; Peru), Izeduwa Derex-Briggs (UNIFEM; Liberia), Elisa Fernández (UNIFEM; Egypt, Kenya, Liberia, Mekong, Peru), Lucia Fort (World Bank; Peru), Anne Golla (ICRW; Egypt, Kenya, Liberia, Mekong, Peru), Caroline Horekens (UNIFEM; Egypt, Kenya, Liberia, Mekong, Peru), Zebib Kavuma (UNIFEM; Kenya), James C. Knowles (World Bank consultant; Mekong) Andrew Morrison (World Bank; Egypt), Maya Morsy (UNIFEM; Egypt), Sahar Nasr (World Bank; Egypt), Greg Ngungi (Consultant UNIFEM; Kenya), Waafas Ofosu-Amaah (World Bank; Kenya, Liberia), Ruth Okoth (UNIFEM; Kenya), Ryratana Rangsitpol (UNIFEM; Mekong), Hiska Reyes (World Bank; Egypt, Kenya, Liberia, Mekong, Peru), Meredith Saggers (ICRW; Kenya, Mekong), Asa Torkelsson (World Bank; Kenya), Martin Valdivia (GRADE, World Bank consultant; Peru). This paper benefited from comments by Jesko Hentschel and Mattias Lundberg (peer reviewers), Stefan Agesborg, Elena Bardasi, Jeni Klugman, Andrew Morrison, Waafas Ofosu-Amaah, and Hiska Reyes. 


\begin{abstract}
Pilot programs have gained significance in donor-supported development instruments because of the growing emphasis on measuring impact. The ResultsBased Initiatives (RBI) were conceived as pioneering pilots expected to acquire rigorous evidence on effective interventions to foster women's economic empowerment. However, they fell short of providing clear or generalizable conclusions on women's economic empowerment due to design and implementation problems. The RBI nevertheless offer important lessons on common traps in pilot design and implementation. This paper synthesizes ten lessons from the RBI as a checklist to avoid pilot failure, intended for practitioners in any area of development.
\end{abstract}

Key words: pilots, impact evaluation, entrepreneurship, training, skills, women, economic empowerment. 


\section{Introduction}

Pilot programs are increasingly becoming a feature in experimenting with innovative approaches to development. It is not difficult to see why. When adequately designed, implemented and evaluated, small scale programs can provide a rigorous, fast and relatively inexpensive testing ground for larger scale interventions. However, small is not always beautiful: without careful planning, implementation and follow-up, pilots may fail. A pilot that shows program failure is not automatically a failure: instead, a pilot failure occurs when the program evaluation cannot provide answers to the question it had set up to address, wasting resources instead of supporting judicious use of development funds. ${ }^{1}$ Building on experience from the Results-Based Initiatives (RBI), this paper derives a checklist designed to navigate more effectively those small, but crucial, obstacles and oversights in pilot design and implementation, and in the evaluation/monitoring methodology that may lead to pilot failure and crash landing.

The RBI were a pioneering program of pilots expected to produce rigorous evidence on effective interventions to foster women's economic empowerment. When conceived by the World Bank and UN Women, then UNIFEM, in 2007, the program was innovative in its use of small scale pilots and rigorous statistical techniques to evaluate the relative effectiveness of different interventions to promote women's economic empowerment in different country settings. The focus on business training interventions as means to reduce gender gaps was also novel since much of the literature and policy dialogue had been centered on gaps in health and education (Mackenzie 2010; McKenzie and Woodruff 2012).

Given their innovative character and scale, the RBI had the potential to provide policy makers with invaluable lessons on the potential impact of different policy packages. Unfortunately, ex-post evaluations show that the program missed that opportunity as the pilot findings were too weak to derive any robust and generalizable conclusions on the effectiveness of alternative interventions. Many lessons on impact therefore remain 'not yet learned'. By contrast, the RBI provide useful lessons on the dos and don'ts of pilot design and implementation for development practitioners.

This paper builds on these lessons to derive a check-list of necessary conditions that need to be satisfied for a pilot to be meaningful and worthwhile. It draws on a set of 
background reports on individual pilots and on two summary reports prepared by United Nations Women (UN Women, previously UNIFEM) and the International Center for Research on Women (ICRW) (UN Women 2011; Golla 2011).

Many of the points raised are common sense and none are new. Some, but not all, relate to the specific requirements of rigorous statistical impact evaluations (IE) in pilots. Nonetheless, pilots continue to fail because these simple points remain systematically neglected in design, implementation and monitoring.

The literature on impact evaluation and project monitoring is vast, and largely directed to a technical audience due to the rigorous statistical methods required to ascertain statistically significant effects (Duflo et al. 2007). Although there have been recent and valuable attempts to present the technical aspects in a simple manner to reach a wide audience (World Bank 2006, Gertler et al. 2010, Khandker et al. 2010), there is a void in presenting some of those lessons using largely non-technical language as is done in the broader monitoring and evaluation strand of papers (World Bank 2004, Bamberger 2009). ${ }^{2}$ The objective of the paper is to fill in this void by presenting a checklist that can help a broad range of interested actors to avoid future costly pilot failures.

The next section summarizes the main design features of the different RBI interventions. Section 3 takes stock of the findings of the individual RBI impact evaluations. Sections 4 focuses on the main lessons learned on pilot design, implementation and monitoring and IE. Section 5 concludes.

\section{The nuts and bolts of the RBI pilots}

The RBI comprised eight country pilots under a common umbrella program whose objective was to generate robust and consistent evidence that could be generalized. This paper focuses on the five RBI that have been implemented and fully evaluated to date. ${ }^{3}$ As shown in Table 1, all single interventions had common elements, but also presented variations in design, implementation, and IE methodology, reflecting differences in local contexts and priorities. The similarities and dissimilarities span the design of the interventions, implementation mode, and IE.

$<$ Table 1 around here $>$ 
The RBI pilots shared many elements. They were small programs with the common objective of fostering women's economic empowerment through enhancement of women's skills, assets, and decision-making. They had limited budgets and were expected to be relatively quick to implement and evaluate. Their common focus was on delivering training and they were all expected to provide measurable and statistically valid evidence on program impact through rigorous IEs. All IEs, except Liberia, used some type of randomized control trial (RCT). Finally, UNIFEM was the common executing agency, relying on local implementation agencies and with a high degree of involvement of government and local non-government organizations (NGO).

However, the interventions also differed substantially in the setting in which they operated and in the design. The program spanned different regions with very different cultural, geographic, and socioeconomic situations. It covered low and middle income countries with different levels of institutional capacity; rural and urban settings; poor and nonpoor groups. In Egypt, Kenya, and Peru they delivered only training, while in Liberia and Mekong training was complemented with grants and equipment. The Egypt pilot aimed at reducing gender wage gaps amongst wage workers, while the others focused on increasing earning capacity of selfemployed women. In Kenya and Peru, training was limited to business skills development, while in Liberia and Mekong this was combined with training on production techniques. The interventions targeted producer groups in Kenya, Liberia and Mekong, but individual entrepreneurs in Peru. They varied also the technical details of the randomization rollout, the final methodology of the IE, the capacity of the implementing agencies, and the government involvement. For example, in Peru the evaluation team was experienced and had previously worked successfully with the implementing agency, and in Egypt the intervention was previously tested in other countries.

The considerable variation in design, methodology and implementation challenges across the different pilots introduced too many degrees of variation to allow generalizable conclusions to be drawn.

\section{Lessons not yet learned on impact}


The impact of the RBI pilots was assessed on three dimensions of women's economic empowerment (World Bank 2011): (i) economic opportunities (ii) endowments — the stock of human capital and assets, and (iii) agency — the ability to make effective choices leading to desired changes. The questions addressed were: (i) what impact did each pilot have on these dimensions; (ii) how reliable are the findings -based on statistical significance/robustness of results and validity of the IE design; and (iii) do consistent messages emerge across countries?

Findings from the individual IEs on each dimension are presented in Tables 2, 3 and 4 respectively. ${ }^{4}$ The main emerging message is the lack of consistent results: the observed impacts were mixed, and the estimates not always reliable.

\subsection{Economic opportunities}

Although promoting economic opportunities was a major objective of the program, no consistent and statistically significant impact on labor market outcomes were found. In Egypt, there was no increase in hiring of women, in Liberia the cassava farina plant did not generate sustainable jobs and in the other pilots the number of women engaged in targeted activities remained constant. Table 2 also shows that the impact on earnings was mostly weak. In Egypt the impact on women's wages and the gender wage gap was statistically insignificant and so was that on revenues of self-employed women in Kenya, Liberia, and Mekong. Only in Peru the intervention led to a statistically significant improvement in business earnings.

Nonetheless, some encouraging findings emerged. In Peru, bookkeeping was introduced, business practices improved, and sales increased by nearly 20 percent when general training was combined with technical assistance in business development. In Mekong, product quality increased and new designs were introduced. In Egypt, male workers displayed stronger awareness of existing gender inequalities, of supervisors' fairness, and of gender equality in career development and training opportunities.

\subsection{Endowments}

The findings on the impact of the interventions on women's labor market skills were more positive. Women in treated Egyptian firms saw their on-the-job training increased. Liberian 
focus groups participants pointed to training in literacy and farming practices as the most useful part of the intervention. However, not all training translated into practice. In Liberia, the suggestion by the trainers to buy in bulk to benefit from lower prices was never adopted. In the Mekong Valley, the splitting machines offered by the project were hardly used because they produced bamboo strips that were too large for small handicrafts.

By contrast, where evaluated - Mekong and Peru — there appeared to be no statistically significant increase in investment in children's education or health, except for a positive impact on boys' education in Lao PDR.

\subsection{Agency}

The interventions showed a mildly positive impact on agency via participation in networks and associations. Participants in Cambodia and Peru reported being more active in decision making over large household expenses after the intervention, but this was not the case in Lao PDR. In the Mekong Valley women moved from home-based to group production of bamboo handicrafts to better learn from each other. In Peru, more women joined business associations and informal lending networks.

$<$ Tables 2, 3, and 4 about here $>$

\section{Lessons learned on pilot design and impact evaluation}

The lack of robust and generalizable results on the impacts of the program is disappointing. Worse is the fact that it is impossible to ascertain the extent to which the weak findings reflect the inherent ineffectiveness of the interventions - intervention failure- as opposed to weaknesses in the design of individual pilots and the umbrella program, their implementation, and evaluation - pilot failure. In this respect the RBI represent a costly missed opportunity to generate valuable evidence on effective levers to improve women's economic environment.

However, the shortcoming of this program can provide a number of lessons on how to avoid basic errors that may limit the potential of pilots from the outset. This section focuses on lessons on pilot design and impact evaluation. A key conclusion is that if time and money are in short supply, expectations need to be managed. Pilots that do not incorporate rigorous 
impact evaluations cannot provide robust knowledge. If the time, resources and capacity to undertake rigorous IEs cannot be found, a more economical evaluation to test the particular program should be considered, based on good quality quantitative and qualitative data.

Table A.1 (in the appendix) shows that the RBI complied with several of the established principles of good practice for IEs. The pilots were justifiable, given the existing knowledge gaps in the area, and they all complied with ethic norms (although not formally approved by ethics committees). Rich - including qualitative- data were collected at the level of the expected impact, and beyond, to capture changes in group dynamics and social norms. Innovative performance indicators were used to monitor difficult to measure outcomes and progress relatively unexplored areas — such as household decision making and group dynamics.

Despite some problems with selection and randomization, ${ }^{5}$ all RBI —except Liberiahad valid control groups reflecting the chosen IE methodology. However compromises had to be made in several areas, including the selection of the control group and the recruitment of beneficiaries. In Kenya and Mekong control villages had to be chosen in different provinces — where inhabitants specialized in different crafts — following severe resentment from individuals in neighboring control villages. Moreover, in 11 of the 43 Mekong villages, the treatment/control decision was based on political consideration rather than randomization. ${ }^{6}$ In Egypt the initial lack of participating firms forced the team to replace the RCT with a quasi-experimental design. Combined with the other weaknesses in design and methodological described below, these problems made it difficult to derive conclusive results, leading to the following lessons.

\section{Lesson 1: be realistic about the learning component}

Balancing ambition with financial resources is a major challenge for pilots. The monitoring, evaluation and learning components are essential parts of all pilot programs, as they ensure their replicability and scaling-up. However, teams should be aware that the learning aspect of pilots can add considerable fixed costs and time requirement, beyond those of small program interventions with same number of beneficiaries. This is due to the higher costs of (i) due diligence and preparation, including of IE; (ii) need for a minimum size (lesson 2), (iii) 
detailed monitoring and evaluation; and (iv) dissemination. It is essential to take this into account in the planning of the intervention and budget accordingly.

The budget envelope for each individual RBI —except for Mekong Valley- was approximately US\$600,000, equally divided between implementation and IE. ${ }^{7}$ The program design -involving building value chains and training in highly complex, low capacity environments and full scale IEs - was too ambitious for the funding. The fact that resources were not explicitly allocated to monitoring or dissemination further limited the capacity to learn from its implementation.

\section{Lesson 2: small is not always beautiful}

Restrictive rules on who can participate are often used to lower the cost of pilot implementation - by lowering transaction costs and making coordination/communication easier. But these rules risk leading to sample sizes that are too small to derive statistically significant conclusions. For the pilot to give results that are meaningful for policy making the number of eligible beneficiaries has to be large enough for the conclusions to be relevant to the whole population of (potential) beneficiaries (external validity), and it needs to be consistent with the evaluation technique chosen to ensure reliability of results (internal validity).

The RBI pilots had a relatively small number of direct beneficiaries - from 250 in Liberia to almost 1,500 in Peru- selected according to geographical or socioeconomic criteria. These small numbers limited their power to give robust results as the participants proved to be too few. Power calculations, of the instrument to determine the sample size needed to provide statistically significant results, were only done for 2 of the 5 pilots. For Peru the sample was sufficiently large; however, this was not the case in the Mekong pilot where a decrease in the number of clusters - from 20 to 18- and the number of observations per cluster indicated the lack of power. ${ }^{8}$ The pilot continued in spite of the predictions about power, suggesting the lack of exit clauses in the setup of the pilots.

\section{Lesson 3: patience is a virtue}

A short time frame is typical of pilot programs and in line with the overarching objective of generating evidence quickly, initiating the policy dialogue promptly, triggering further 
research, and/or scaling up the intervention. However, a compressed time frame risks cutting down essential stages of the process and reducing the attention given to pilot development, including client consultations. It can also shorten the time devoted to understanding the theory behind the intervention: its expected impacts, the mechanisms through which the impacts will be achieved, and the potential distributional effects. Ultimately it may result in delays along the way due to a higher number of unforeseeable adjustments.

The RBI were expected to show quick results - within one to two years of project initiation. Overall this time frame was too ambitious for programs that involved complex change processes, including improvements along the entire value chain (Liberia, Kenya, Mekong), organizational development, changed preferences and attitudes in the private/public spheres, improvement in business practices, and changed relations at household level. Achieving such complex transformations is a difficult and time-consuming task -irrespectively of the size of the program - that requires capacity among implementers to monitor progress and to adopt intervention accordingly. Although rooted in extensive feasibility studies, the planning phase and the training of local partners took longer than expected partially due to low capacity on the ground, especially in the complex Liberia, Kenya and Mekong pilots. Delays in the design and planning translated also in further time pressure in the implementation phase. For example, in Mekong 15 villages were added to the project after the baseline collection was fielded and the team decided not to collect any data for them, and left them out of the IE.

The experience with the RBI shows the importance of balancing time pressures against the benefits of good planning, of allowing enough time for implementation and adaptation, for a solid IE to be carried out and for learning. Setting up and testing the logistical arrangements, and feeding the findings back into the design of the intervention, take time but it is invaluable to the success of the pilot. In some cases, existing work can feed into the process but, when prior evidence is scarce, it is also important to conduct focus group discussions, or field-test the intervention. For example, in Peru, an experiment focusing on training related to the RBI intervention was launched just before the program and served to inform and improve the program (Karlan and Valdivia 2011). 
Lesson 4: focus on the recruitment stage

The recruitment stage is critical to the success of interventions that are inherently small scale because a further reduction in sample size lowers the probability of finding statistically significant impacts. Interventions focusing on business development skills appear particularly prone to recruitment problems (McKenzie and Woodruff 2012). The RBI were not exceptions and they all faced difficulties in recruitment, except Liberia, where the group was pre-selected and there was no control group. There were problems in recruiting enough firms (Egypt, Kenya, and Peru), finding enough villages (Mekong) and randomizing among them. ${ }^{9}$ The level of the randomization and the final sample size is given in Table 5 .

A number of factors may lead to difficulties in recruitment including the time that takes targeting potential beneficiaries to learn about the intervention, mobility constraints that may limit the accessibility of the interventions, and an underestimation of the potential payoffs of the intervention by potential beneficiaries. It is essential for teams to allocate enough resources and time to adequately address these challenges.

However, it is also important to acknowledge that participating in the treatment has a cost including foregone labor earnings and potential beneficiaries may rationally decide that the expected payoff is not enough to cover the participation cost. Teams should then see recruitment difficulties as a flag for the relevance of the program and/or its accessibility for targeted beneficiaries and consider alternative designs.

$<$ Table 5 around here $>$

Lesson 5: select indicators early and make sure they are measurable and meaningful

Selecting appropriate performance indicators is a challenging but critical step for the evaluation stage because it influences not only the measurement but also the multiple channels through which impacts transpire. It is essential to select indicators early during pilot design and ensure they are measurable and meaningful, keeping in mind that measurable changes can only be expected where there is scope for improvement, and if sufficient time is given for the different processes to take place. 
Measuring impact on business outcomes is a complex task due to measurement errors in firm profits, revenues, and sales (de Mel, McKenzie, and Woodruff 2009) and because the intervention can affect the reporting of business outcomes (McKenzie and Woodruff 2012). Pilots on female economic empowerment face additional challenges in measuring impacts on agency, both as a final goal and as instrument for better economic opportunities.

Doing so was particularly challenging for the RBI due to the limited evidence then available on measuring empowerment and identifying levers to enhance it (Narayan 2005). The pilot developed several innovative approaches relying on questions that are innately subjective. ${ }^{10}$ But not all indicators proved meaningful or measurable and in some cases inconsistent answers between men and women, or over time, were recorded.

Lesson 6: supplement quantitative data with quality qualitative information

Good quality data is another essential element of a successful pilot and using mixed methods provides a broader understanding of the results and associated processes, especially with limited budgets.

Reliable quantitative data require a large sample to minimize measurement error and collection of quantitative information on some indicators - consumption, empowermentrequires high capacity of local agencies and enumerators. It also requires time - especially if new questions/indicators are introduced - because questionnaires need to be tested and some variables need time to be collected or to show changes. Qualitative data can usefully complement quantitative information and reduce the time and resources needed to meet the quality standard. Qualitative data collected at a preliminary stage and thorough testing of the survey instruments can help provide evaluators with better understanding of the baseline levels of key indicators and therefore provide a basis for comparison.

All RBI pilots, except Liberia, collected both quantitative and qualitative data. The IE of the Mekong RBI was particularly successful in using mixed methods in the evaluation. The quantitative questionnaire included eight questions (with up to eight answers) on decision making about bamboo handicraft products (BHP) and several questions on division of labor within the household. The qualitative work was instrumental in interpreting the findings on gender roles. In Laos, it indicated that there was a large increase in the percentage of BHP 
related decisions made by females, and women felt in control of the money generated by the sales of BHP, which they used mostly to buy food in the market.

\section{Lesson 7: measure impacts at level at which change occurs}

It is essential to collect data at the level at which changes occur even though this may require a larger sample size. If the project works primarily to create change at enterprise (group/village) level, for example, impact should be measured and data collected at that level.

The RBI pilots collected data at several levels and in most cases measured the impact at the level the change was expected to occur: individual, household, producer group, or firm. In Egypt where the impact was expected at firm-level, data were collected with a firm questionnaire —administrated to the human resources department of each firm - and an employee questionnaire — to human resources department and workers. However, in Kenya and Liberia, due to problems during the implementation stage, the evaluations focused on individual level impacts, despite group level implementation of the interventions. This discrepancy may partially explain the statistical weakness of the results in these countries.

Lesson 8: monitor progress along the way and continue to do so

Another main lesson is the importance of choosing indicators that change at different times and planning for several rounds of final data collection. There is no simple rule on the optimal time-frame for IE. The optimal lag in collecting endline data depends on the theory of change - that is on the type of changes expected and on the performance indicators chosen. Enhancing female economic empowerment is a complex process that requires time and capacity among implementers to monitor progress regularly and to adapt the intervention accordingly. Indicators of final impacts should be complemented with immediate and intermediate impact indicators that can be monitored within shorter time frames and tend to be easier to measure. These indicators are also useful to gain information on the transmission channels and on emerging barriers that may prevent final impacts from materializing. Moreover, in this way the long term trajectory of the impact can be identified (Woolcock 2009). 
Most RBI pilots collected endline data within six months from the end of the intervention. In retrospect, this time-frame was too short to be able to observe the full impacts of the interventions, let alone the trajectory of impact, especially given their ambitious objectives and the performance indicators selected. In Peru, for example, initial endline data showed impacts on sales only for women who benefited from both the general training and the technical assistance, while the indicators on intermediate impacts bookkeeping, enrollment in business/financial associations - showed positive impacts for all beneficiaries. A second round of data collected a year later mostly confirmed the results on intermediate outcomes but also showed a slightly higher increase in sales (Valdivia 2011b).

Lesson 9: if you are aiming for generalizable results, be consistent

Programs that aim for generalizable results require consistency in design, implementation, and IE methodologies across interventions. Adapting interventions to reflect country context and needs, threatens the generalization of findings. Using different IE methodologies weakens the robustness of results. Thus teams need to weigh the tradeoffs between reflecting country contexts and obtaining lessons that hold across interventions in line with the objective of the overarching program.

The RBI varied considerably in design, choice of beneficiaries, implementation, and IE methodology. The cross-pilots variation proved to be too high to allow for generalizable conclusions to be drawn. Given that this was a major objective of the program, more weight should have been given to having consistency at all stages of the interventions.

\section{Lesson 10: remember just-in-time monitoring}

Finally the role of just-in-time monitoring in avoiding pilot failures should not be underestimated. Monitoring is part of the due diligence to ensure that resources are spent adequately. It also allows for early detection of problems and, if combined with effective feed-back mechanisms, for real-time fine-tuning of the program, or possible early exit. This is particularly important for pilots because their innovative features may require more adaptation during implementation than more established interventions. Finally, monitoring can contribute to reconstructing the story behind success/failure and understanding the 
underlying transmission mechanisms (Bamberger, Rao, and Woolcock 2010; Rao and Woolcock 2003).

All RBI included a monitoring system and a detailed common protocol was produced. In practice this was rarely followed however and the monitoring efforts varied across pilots in design, feedback mechanisms, and depth of information collection. For example, the Kenya monitoring plan included several monthly collected indicators —including increase in individual/group sales, and business turnover. In Peru, more detailed records on progress were provided through in-depth interviews with selected beneficiaries. However, generally regular monitoring fell significantly short of what initially envisaged, real time feedback was limited and never fully incorporated in program adaptation. This may have been one of the major factors behind the failure of the RBI to generate the results they were set up to achieve.

\section{Towards a checklist to avoid pilot failures}

Pilot interventions are a growing feature of innovative approaches to development. However, the experience of the RBI shows that pilot programs need careful planning, implementation and follow-up in order to provide useful results. Even small shortcomings and deviations from a few simple 'golden rules' may result in large departures from the initial objectives of the program and may lead to pilot failure. Box 1 maps the ten lessons learnt from this experience — and those not learnt - to corresponding items in a simple checklist designed to help practitioners avoid further costly missed opportunities.

\section{Box 1: A checklist to avoid pilot failures}

Budget aligned with expectations and resources enough to incorporate learning component in addition to financing pilot intervention

Number of subjects in sample large enough to provide results that are statistically significant at population level if IE is part of the design

$\square$ Timeline of the intervention does not compromise good planning and learning allows for adaptation if needed

Potential recruitment issues analyzed and tackled and adequate time allocated tom inform potential beneficiaries 
$\square$ Enough time allocated between the intervention and the endline data collection to allow processes to take place.

$\square$ Provision for collection of quality quantitative and qualitative data, including multiple rounds.

$\square$ Data collection envisaged at level of expected impact, including multiple levels if needed

$\square$ Wide range of intermediate and final impact indicators which are measurable and meaningful

$\square$ Individual components of umbrella program designed and implemented to obtain comparable and generalizable lessons.

$\square$ Monitoring system designed to provide real time feedback on progress and system in place to feed findings into intervention design and implementation

\section{Acknowledgements}

$<$ Acknowledgements about here $>$

\section{Notes}

1. Conversely, a pilot showing program success does not guarantee that the program can be successfully replicated in a different setting or scaled up. These issues that are beyond the scope of this paper, however.

2. A glossary of the few technical terms used here can be found in Gertler et al. (2010).

3. Only five programs have been implemented and fully evaluated: Arab Republic of Egypt, Kenya, Liberia, Mekong Valley, and Peru. Three programs were added at a later stage and are still to be evaluated: Ghana, Nicaragua, and Tanzania.

4. These findings are discussed in more detail in Johansson, Paci, and Posadas (2014).

5. Randomization was affected by leakages and contamination between the treatment and the control groups given the proximity of villages.

6. For more details see Knowles (2011) Table 1.

7. The expenses for data collection and M\&E were: US\$110,624 in Egypt, US\$102,732 in Kenya, US\$ 89,995 in Liberia, US\$302,084 in Mekong, and US\$165,674 in Peru. Figure 1 
in Woeller (2010) summarizes the implementation costs per country: US\$226,285 in Egypt, US\$305,000 in Kenya, US\$315,000 in Liberia, US\$640,000 in Mekong and US $\$ 290,411$ in Peru. The cost of the evaluation analysts was not itemized.

8. In the end, the number of clusters was maintained but the number of observations per cluster remained below the minimum.

9. In Peru, the implementing team decided to expand geographically to the South Cone of Lima after failure to adequately reach eligible firms had led to poor response in the North Cone.

10. The Demographic and Health Surveys are one exception but they mainly focus on questions about decision making.

\section{References}

Bamberger, Michael. 2009. Strengthening the evaluation of programme effectiveness through reconstructing baseline data. Journal of Development Effectiveness 1(1), 37-59.

Bamberger, Michael, Vijayendra Rao, and Michael Woolcock. 2010. Using mixed methods in monitoring and evaluation. World Bank Policy Research Working Paper No. 5245. World Bank Group, Washington, DC.

de Mel, Suresh, David McKenzie, and Christopher Woodruff. 2008. Returns to capital in microenterprises: Evidence from a field experiment. Quarterly Journal of Economics 123(4), 1329-72.

De Mel, Suresh, David McKenzie, and Christopher Woodruff. 2009. Are women more credit constrained? Experimental evidence on gender and microenterprise returns. American Economic Journal: Applied Economics 1(3), 1-32.

Duflo, Esther, Rachel Glennerster, and Michael Kremer. 2007. "Using randomization in development economics research: A toolkit" Chapter 61 in Handbook of Development Economics, Vol.4, 3895-3962 edited by T. Paul Schultz and John Strauss. Elsevier, North Holland.

Fafchamps, Marcel, David McKenzie, Simon Quinn, and Christopher Woodruff. 2011. When is capital enough to get female enterprises growing? Evidence from a randomized experiment in Ghana. World Bank Policy Research Working Paper No. 5706. World Bank, Washington, DC.

Gertler, Paul J., Sebastian Martinez, Patrick Premand, Laura B. Rawlings, and Christel M. J. Vermeersch. 2011. Impact Evaluation in Practice. Washington, DC: World Bank. 
Golla, Anne Marie. 2011 Impact evaluation for the small-scale project: What do managers need to know? Lessons learned from the Results-Based Initiatives (RBI) Program. International Center for Research on Women, mimeo.

Golla, Anne Marie, and Annie Jones-Demen. 2011. Results-Based Initiatives Program Liberia: Value-added cassava enterprise for the Ganta Concern Women's Group in Liberia. International Center for Research on Women, mimeo.

Golla, Anne, and Meredith Saggers. 2011. Kenya Results-Based Initiatives Program: Strengthening export competitiveness of women bead workers." International Center for Research on Women, mimeo.

Golla, Anne Marie, and Mona Selim. 2011. Egypt Results-Based Initiatives: Promoting gender equality and productivity in the private firms in Egypt; The Gender Equity Model Egypt. Impact evaluation report, International Center for Research on Women, mimeo.

Johansson, Sara, Pierella Paci, and Josefina Posadas.2014. Lessons learned and not yet learned from a multicountry initiative on women's economic empowerment. World Bank Study No.83276. World Bank, Washington DC.

Karlan, Dean, and Martin Valdivia. 2011. Teaching entrepreneurship: Impact of business training in microfinance clients and institutions. Review of Economics and Statistics 93(2), 510527

Khandker, Shahidur R., Gayatri B. Koolwal, and Hussain Samad. 2009. Handbook on Quantitative Methods of Program Evaluation. World Bank, Washington, DC.

Knowles, Jim. 2011. Final report: Impact evaluation of the Mekong Results-Based Intervention. World Bank, Washington, DC, mimeo.

McKenzie, David. 2010. Impact assessments in finance and private sector development: What have we learned and what should we learn? World Bank Research Observer, 25(2), 209-33.

McKenzie, David, and Christopher Woodruff. 2012. What are we learning from business training and entrepreneurship evaluations around the developing world? World Bank Policy Research Working Paper No. 6202, World Bank, Washington, DC.

Narayan, Deepa. 2005. Measuring empowerment: Cross-disciplinary perspectives. World Bank. Washington, DC.

Rao, Vijayendra, and Michael Woolcock. 2003. Integrating qualitative and quantitative approaches in program evaluation. In The Impact of Economic Policies on Poverty and Income Distribution: Evaluation Techniques and Tools, eds. Francois J. Bourguignon and Luiz Pereira da Silva, 165-90. New York: Oxford University Press. 
Valdivia, Martin. 2011a. Training or technical assistance for female entrepreneurship? Evidence from a field experiment in Peru. World Bank, mimeo.

Valdivia, Martin. 2011b. Training or technical assistance for female entrepreneurship? Evidence from the second follow-up for the Peruvian field experiment. World Bank, mimeo.

UN Women. 2011. Results-Based Initiatives program evaluation: Report on findings." Authored by Woller, Gary, UN Women, mimeo.

Woolcock, Michael. 2009. Toward a plurality of methods in project evaluation: a contextualised approach to understanding impact trajectories and efficacy. Journal of Development Effectiveness, 1, 1-14.

World Bank. 2004. Monitoring and Evaluation: Some Tools, Methods, and Approaches. World Bank-OED Working Paper No.24614.

World Bank. 2006. Conducting Quality IEs under Budget, Time, and Data Constraints. World Bank, Washington, DC.

World Bank. 2011. Gender Equality and Development: World Development Report 2012. World Bank, Washington, DC.

\section{Appendix 1.}

$<$ Table Appendix A1 about here> 
Table 1. Summary of RBI pilot interventions.

\begin{tabular}{|c|c|}
\hline Objectives & Intervention \\
\hline $\begin{array}{l}\text { Egypt: Gender equity model } \\
\text { Improve gender equity in access } \\
\text { to jobs, wages, career } \\
\text { development, working } \\
\text { conditions, and employment } \\
\text { participation. }\end{array}$ & $\begin{array}{l}\text { Foster good gender equity practices in the private sector by } \\
\text { helping firms formulate and achieve gender equity goals } \\
\text { through human resources training. }\end{array}$ \\
\hline $\begin{array}{l}\text { Kenya: Strengthening export competitivene } \\
\text { Increase productivity and } \\
\text { earnings of women in beadwork } \\
\text { by increasing access to export } \\
\text { markets. }\end{array}$ & $\begin{array}{l}\text { f women beadworkers } \\
\text { Provide training and mentoring to improve design, } \\
\text { marketing, and business skills; help identify and access larger } \\
\text { markets. }\end{array}$ \\
\hline $\begin{array}{l}\text { Liberia: V alue-added cassava enterprise } \\
\text { Increase economic security, } \\
\text { strengthen livelihoods, empower } \\
\text { participants, and promote the } \\
\text { cassava industry as a growth sector } \\
\text { and poverty reduction strategy. }\end{array}$ & $\begin{array}{l}\text { be Ganta Concern Women's Group } \\
\text { (i) Training on improved farming techniques for growing } \\
\text { cassava; (ii) activities in the Ganta group to help them } \\
\text { negotiate for more land; (iii) grants to pay for tools, } \\
\text { purchasing inputs, and so forth.; (iv) a cassava farina plant; } \\
\text { and (v) additional activities to strengthen the organization's } \\
\text { governance and gender sensitivity. }\end{array}$ \\
\hline $\begin{array}{l}\text { Mekong: Improving bamboo handicraft va } \\
\text { Increase productivity and earnings } \\
\text { of women in the bamboo } \\
\text { handicraft trade. }\end{array}$ & $\begin{array}{l}\text { chains for women's economic empowerment } \\
\text { (i) Groups training on production of bamboo handicraft } \\
\text { products; (ii) study tour for producer groups and traders; } \\
\text { and (iii) equipment. }\end{array}$ \\
\hline $\begin{array}{l}\text { Peru: Strengthening the economic empower } \\
\text { Increase productivity of women } \\
\text { microentrepreneurs and their } \\
\text { bargaining power in household. }\end{array}$ & $\begin{array}{l}\text { nt of women microentrepreneurs in Lima } \\
\text { Provide training in business practices, marketing, and life } \\
\text { skills to women micro-entrepreneurs with land title (and } \\
\text { thus collateral for credit) }\end{array}$ \\
\hline
\end{tabular}
Source: Authors' compilation. 
Table 2. Impacts on economic opportunities.

\begin{tabular}{|c|c|c|c|c|c|}
\hline & $\begin{array}{l}\text { Women's labor force } \\
\text { participation }\end{array}$ & Technology of production & Wages and sales & Career & $\begin{array}{l}\text { Statistically } \\
\text { reliable results? }\end{array}$ \\
\hline $\begin{array}{l}\text { Egypt, } \\
\text { Arab } \\
\text { Rep. of }\end{array}$ & $\begin{array}{l}\text { Absenteeism increased for } \\
\text { both men and women in } \\
\text { the GEME-treated firms. } \\
\text { However, this result can be } \\
\text { driven by seasonality } \\
\text { effects. }\end{array}$ & Not applicable. & No effects on gender wage gap. & $\begin{array}{l}\text { No effects at firm } \\
\text { level on hiring, } \\
\text { training, } \\
\text { promotion, or } \\
\text { representation of } \\
\text { women in } \\
\text { management. }\end{array}$ & $\begin{array}{l}\text { YES } \\
\text { With caution due to } \\
\text { (i) heavy reliance on } \\
\text { self-reported } \\
\text { information, and (ii) } \\
\text { no robust statistical } \\
\text { specification. }\end{array}$ \\
\hline Kenya & $\begin{array}{l}\text { No new workers attracted } \\
\text { to bead handicrafts. } \\
\text { Beneficiaries initiated other } \\
\text { income-generating } \\
\text { activities. }\end{array}$ & $\begin{array}{l}\text { Groups did not embrace } \\
\text { suggestion to purchase in bulk to } \\
\text { lower input price. } \\
\text { Introduction of new designs had } \\
\text { no impact. }\end{array}$ & $\begin{array}{l}\text { No effect on sales strategies or traders' } \\
\text { performance at group level. } \\
\text { No effect on revenues of beneficiaries in } \\
\text { either bead-only work or in groups that } \\
\text { combined beadwork with other activities. }\end{array}$ & Not applicable. & $\begin{array}{l}\text { NO } \\
\text { Weak IE design. } \\
\text { Weak } \\
\text { implementation: } \\
\text { curricula of training. }\end{array}$ \\
\hline Liberia & $\begin{array}{l}\text { Very few paid jobs created, } \\
\text { and these jobs were only } \\
\text { available to those living } \\
\text { near Ganta Concern } \\
\text { Women's Group. }\end{array}$ & $\begin{array}{l}\text { Class training on farming } \\
\text { practices had no effect. On-site } \\
\text { field demonstrations were } \\
\text { effective. } \\
\text { Plant operates at less than } 10 \\
\text { percent of capacity. }\end{array}$ & $\begin{array}{l}\text { Increased access to land and labor, and } \\
\text { improved farming techniques, leading to } \\
\text { higher cassava production in group } \\
\text { farms but with high variability of impacts } \\
\text { across groups. } \\
\text { Caveat: the cassava was sold only to the } \\
\text { processing plant which could not process } \\
\text { it and many fields remain unharnessed. }\end{array}$ & Not applicable. & $\begin{array}{l}\text { NO } \\
\text { Weak IE design: no } \\
\text { valid control group. } \\
\text { Weak intervention } \\
\text { design: } \\
\text { underestimated } \\
\text { constraints such as } \\
\text { literacy. }\end{array}$ \\
\hline Mekong & $\begin{array}{l}\text { No change in the } \\
\text { probability of households } \\
\text { producing BHP. }\end{array}$ & $\begin{array}{l}\text { Increase in quality and new } \\
\text { designs. Bamboo-splitting } \\
\text { machines not used. No effect } \\
\text { on access to raw bamboo. }\end{array}$ & $\begin{array}{l}\text { No effect on the share of bamboo } \\
\text { activity in household income } \\
\text { Sales increased during the low season, } \\
\text { but only in Cambodia. }\end{array}$ & Not applicable. & $\begin{array}{l}\text { NO } \\
\text { Weak IE design: } \\
\text { small sample. }\end{array}$ \\
\hline Peru & $\begin{array}{l}\text { A few beneficiaries closed } \\
\text { their businesses, possibly } \\
\text { because they realized the } \\
\text { businesses were not viable, } \\
\text { but may also reflect the } \\
\text { normal high exit rate of } \\
\text { small firms. }\end{array}$ & $\begin{array}{l}\text { Women who received GT+TA } \\
\text { introduced a few good business } \\
\text { practices (bookkeeping and } \\
\text { executing innovations) and } \\
\text { increased reliance on formal } \\
\text { credit; use of informal credit } \\
\text { increased for all beneficiaries. }\end{array}$ & $\begin{array}{l}\text { Sales increased by } 19 \text { percent among } \\
\text { women that received GT+TA. In a } \\
\text { second round, results remained positive, } \\
\text { but their size slightly decreased and their } \\
\text { variation increased. }\end{array}$ & Not applicable. & $\begin{array}{l}\text { YES } \\
\text { Robust design and } \\
\text { implementation + } \\
\text { credible IE. }\end{array}$ \\
\hline
\end{tabular}


Table 3. Impacts on endowments.

\begin{tabular}{|c|c|c|c|c|}
\hline & Women's labor market skills & $\begin{array}{l}\text { Children's health, nutrition, } \\
\text { and education }\end{array}$ & Assets & $\begin{array}{c}\text { Statistically } \\
\text { reliable results? }\end{array}$ \\
\hline $\begin{array}{l}\text { Egypt, } \\
\text { Arab } \\
\text { Rep. of }\end{array}$ & $\begin{array}{l}\text { Women in treated firms received on- } \\
\text { the-job training and their perceptions of } \\
\text { their labor market skills improved. }\end{array}$ & Not measured. & $\begin{array}{l}\text { Not } \\
\text { measured. }\end{array}$ & $\begin{array}{l}\text { YES } \\
\text { Based on self-reporting by } \\
\text { workers. }\end{array}$ \\
\hline Kenya & $\begin{array}{l}\text { Training in new designs, but no changes } \\
\text { were observed in the beads produced. } \\
\text { Women valued exposure to trade } \\
\text { fairs/market places. }\end{array}$ & Not measured. & $\begin{array}{l}\text { Reduction in } \\
\text { group's } \\
\text { savings and } \\
\text { material } \\
\text { assets. }\end{array}$ & $\begin{array}{l}\text { NO } \\
\text { Weaknesses in design and } \\
\text { implementation. }\end{array}$ \\
\hline Liberia & $\begin{array}{l}\text { Mixed reactions to training for } \\
\text { agricultural practices; } \\
\text { most women were not interested in } \\
\text { classroom training, but did value the } \\
\text { literacy training. }\end{array}$ & Not measured. & $\begin{array}{l}\text { Not } \\
\text { measured. }\end{array}$ & $\begin{array}{l}\text { NO } \\
\text { Weaknesses in design and } \\
\text { implementation. }\end{array}$ \\
\hline Mekong & $\begin{array}{l}\text { Training of the trainers succeeded, with } \\
1,354 \text { group participants, most of who } \\
\text { were women; who perceived the training } \\
\text { as useful. }\end{array}$ & $\begin{array}{l}\text { Increase in spending on boys' education in } \\
\text { Lao PDR; decreased spending on personal } \\
\text { care items for men; no effect on child labor. }\end{array}$ & $\begin{array}{l}\text { Not } \\
\text { measured. }\end{array}$ & $\begin{array}{l}\text { YES } \\
\text { With caution, based on self- } \\
\text { reporting by producers. }\end{array}$ \\
\hline Peru & $\begin{array}{l}\text { Increase in women's time devoted to } \\
\text { studies for those that received both } \\
\text { training and targeted assistance; } \\
\text { decreased for those who received only } \\
\text { training. }\end{array}$ & $\begin{array}{l}\text { Decrease in time other females in the } \\
\text { household spent in business and other work, } \\
\text { for beneficiaries of both training and targeted } \\
\text { assistance; } \\
\text { no effect on time spent on studies by } \\
\text { children ( } 7-13 \text { years old). }\end{array}$ & $\begin{array}{l}\text { Increase in } \\
\text { the use of } \\
\text { informal } \\
\text { credit } \\
\text { (though there } \\
\text { is some } \\
\text { crowding out } \\
\text { of formal } \\
\text { credit). }\end{array}$ & $\begin{array}{l}\text { YES } \\
\text { Robust design and } \\
\text { implementation, credible IE }\end{array}$ \\
\hline
\end{tabular}


Table 4. Impacts on agency.

\begin{tabular}{|c|c|c|c|c|}
\hline & Household decision process & Groups and networks & Perceptions & $\begin{array}{l}\text { Statistically } \\
\text { reliable results? }\end{array}$ \\
\hline $\begin{array}{l}\text { Egypt, } \\
\text { Arab } \\
\text { Rep. of }\end{array}$ & Not applicable. & Not applicable. & $\begin{array}{l}\text { Employee satisfaction increased for } \\
\text { both men and women. } \\
\text { Awareness of gender equality } \\
\text { increased for both men and women. } \\
\text { Mixed results on workplace: } \\
\text { discrimination increased (women } \\
\text { only) and experiences of a hostile } \\
\text { work environment decreased. }\end{array}$ & $\begin{array}{l}\text { YES } \\
\text { With caution, } \\
\text { many outcomes rely } \\
\text { on self-reported } \\
\text { information. } \\
\text { Weak design: small } \\
\text { sample. }\end{array}$ \\
\hline Kenya & Not measured. & $\begin{array}{l}\text { No change in the number of groups } \\
\text { registered or the average number of group } \\
\text { members. }\end{array}$ & $\begin{array}{l}\text { Young women with some education } \\
\text { perceived the project as beneficial. } \\
\text { Market visits and trade fairs found } \\
\text { useful to learn about marketing } \\
\text { strategies. }\end{array}$ & $\begin{array}{l}\text { NO } \\
\text { Weak IE design: } \\
\text { small sample. }\end{array}$ \\
\hline Liberia & $\begin{array}{l}\text { Some women reported feeling more } \\
\text { confident and having higher self-esteem. } \\
\text { Families' perceptions about group's work } \\
\text { were mixed due to extensive time } \\
\text { commitment of beneficiaries with little } \\
\text { economic return. }\end{array}$ & $\begin{array}{l}\text { Membership in group did not change. } \\
\text { No ability to manage the plant independently. } \\
\text { No sense of ownership toward the enterprise, } \\
\text { and no sense of responsibility. } \\
\text { Diagnostic of the organizational problems did } \\
\text { not engage the group in seeking changes. } \\
\text { Leadership training, valued by individuals, did } \\
\text { not affect group governance or transparency. }\end{array}$ & $\begin{array}{l}\text { Overall sense of dissatisfaction with } \\
\text { the intervention. Group leaders } \\
\text { would have preferred guidance with } \\
\text { the management of Ganta and not } \\
\text { the building of the farina plant. } \\
\text { Some satisfaction with training in } \\
\text { farming techniques. }\end{array}$ & $\begin{array}{l}\text { NO } \\
\text { Based mostly on } \\
\text { qualitative data from } \\
\text { focus groups. }\end{array}$ \\
\hline Mekong & $\begin{array}{l}\text { Significant positive effects on likelihood of } \\
\text { bulk purchases (Cambodia only). } \\
\text { No significant effects on gender roles in } \\
\text { BHP-related decisions. } \\
\text { No effect on gender roles within the HH. }\end{array}$ & $\begin{array}{l}\text { Increased number of households working with } \\
\text { a producer group. }\end{array}$ & $\begin{array}{l}\text { Perceived constraints were: access } \\
\text { to inputs (too expensive), access to } \\
\text { traders, low product prices. }\end{array}$ & $\begin{array}{l}\text { NO } \\
\text { Weak design: lack of } \\
\text { statistical power to } \\
\text { control for clusters. }\end{array}$ \\
\hline Peru & $\begin{array}{l}\text { Increased women's participation in } \mathrm{HH} \\
\text { decision process for those that receive both } \\
\text { GT+TA. Larger effects among young, } \\
\text { single, less educated beneficiaries with land } \\
\text { title and medium dependence on business. }\end{array}$ & $\begin{array}{l}\text { Increased participation in business associations } \\
\text { for all beneficiaries. }\end{array}$ & $\begin{array}{l}\text { Increased acceptance of working } \\
\text { women. } \\
\text { No effect on perception of gender } \\
\text { roles within the HH. }\end{array}$ & $\begin{array}{l}\text { YES } \\
\text { Robust design and } \\
\text { implementation and } \\
\text { credible IE. }\end{array}$ \\
\hline
\end{tabular}

Source: Authors' compilation based on Golla and Jones-Demen (2011); Golla and Saggers (2011); Golla and Selim (2011); Golla (2011); Knowles (2011); and Valdivia (2011a, 2011b). Notes: BDS = business development skills; BHP = bamboo handicraft product; Ganta = Ganta Concern Women's Group; GT = general training; HH = household; TA = technical assistance. 
Table 5. Randomization, clusters, and sample size.

\begin{tabular}{|c|c|c|c|c|c|}
\hline Country & IE Method & Cluster & $\begin{array}{c}\text { Stratification/Matching } \\
\text { Variables }\end{array}$ & $\begin{array}{l}\text { Number of } \\
\text { participants }\end{array}$ & $\begin{array}{c}\text { Cluster and } \\
\text { individual } \\
\text { take up rate }\end{array}$ \\
\hline Egypt & $\begin{array}{c}\text { Randomization } \\
\text { of matched } \\
\text { pairs }\end{array}$ & Firm & $\begin{array}{c}\text { Economic sector, size, } \\
\text { gender composition of } \\
\text { work force, and gender } \\
\text { policies }\end{array}$ & $\begin{array}{c}16 \text { firms, } 1040 \\
\text { employees }\end{array}$ & $\begin{array}{l}80 \% \text { firms; } \\
59 \% \\
\text { employees }\end{array}$ \\
\hline Kenya & $\begin{array}{l}\text { Randomization } \\
\text { of matched } \\
\text { pairs }\end{array}$ & Village & $\begin{array}{l}\text { Village size, distance to a } \\
\text { main road, beadwork and } \\
\text { IGA experience }\end{array}$ & $\begin{array}{l}23 \text { producer groups, } \\
\text { ranging from } 7 \text { to } 70 \\
\text { members }\end{array}$ & $\begin{array}{c}\text { Initially: } 50 \% \\
\text { groups; } \\
\text { After } \\
\text { additional } \\
\text { recruiting: } \\
\text { 58\% groups }\end{array}$ \\
\hline Liberia & $\begin{array}{l}\text { First difference } \\
\text { (comparing } \\
\text { results before } \\
\text { and after) }\end{array}$ & $\mathrm{n} / \mathrm{a}$ & & $\begin{array}{l}246 \text { women of } \\
\text { Ganta’s producer } \\
\text { group }\end{array}$ & $\mathrm{n} / \mathrm{a}$ \\
\hline Mekong & $\begin{array}{l}\text { Randomization } \\
\text { of matched } \\
\text { pairs }\end{array}$ & Village & $\begin{array}{l}\text { Village population, district } \\
\text { location, percentage of } \\
\text { households in BHP, type } \\
\text { of BH products, type of } \\
\text { traders. }\end{array}$ & $\begin{array}{c}43 \text { villages (or } \\
\text { bamboo handicraft } \\
\text { groups), } 986 \mathrm{BHP} \\
\text { households }\end{array}$ & $\begin{array}{l}85 \% \text { villages } \\
\text { due to non- } \\
\text { random } \\
\text { assignment to } \\
\text { treatment and } \\
\text { control; }\end{array}$ \\
\hline Peru & $\begin{array}{l}\text { Randomized } \\
\text { control trial }\end{array}$ & Individual & Districts/neighborhoods & $\begin{array}{l}1983 \text { female micro- } \\
\text { entrepreneurs }\end{array}$ & $51 \%$ women \\
\hline
\end{tabular}


Table A1. Mapping RBIs features to best practice principles of impact evaluation.

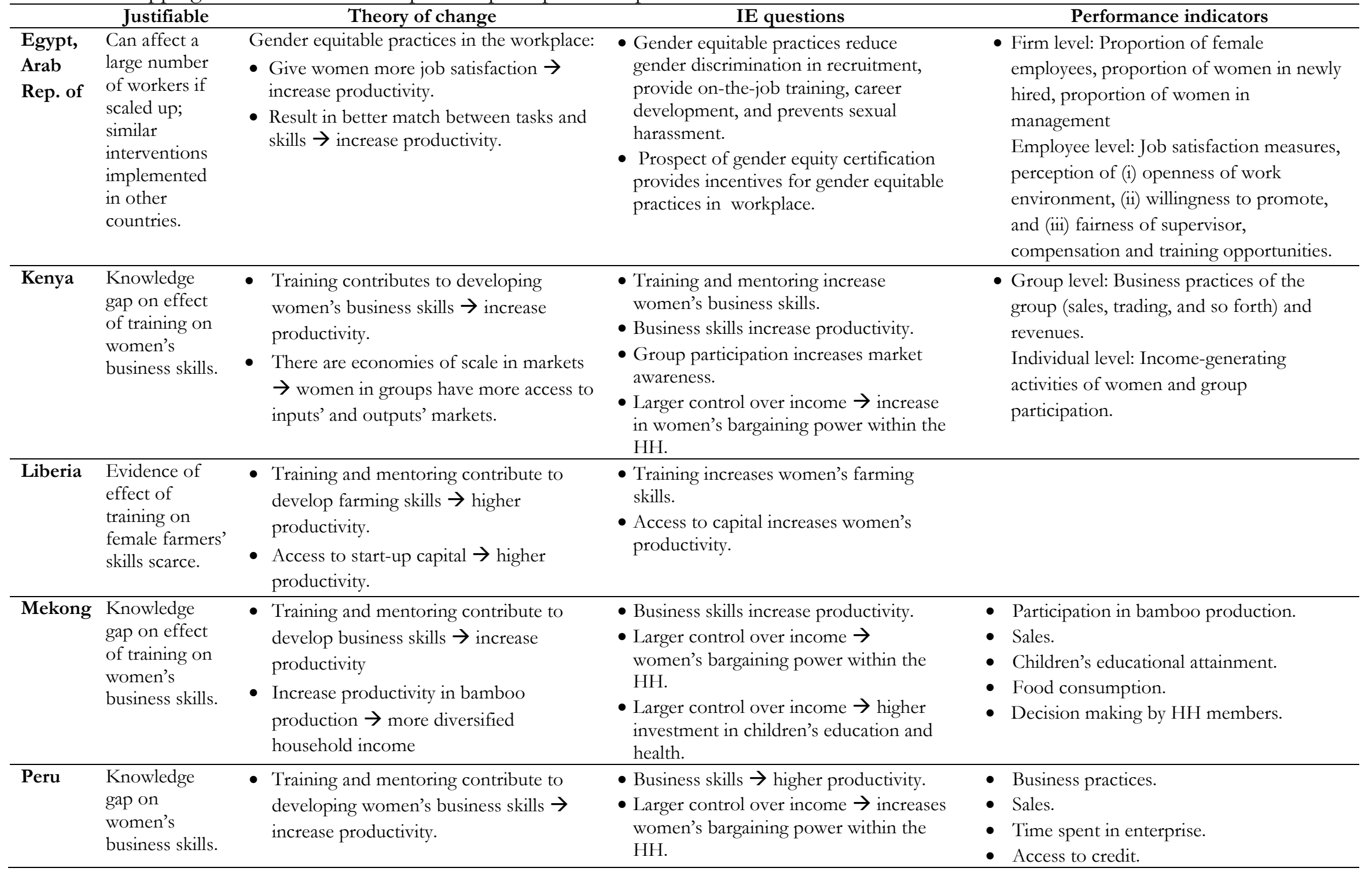


Table A1. Continued

\begin{tabular}{|c|c|c|c|c|c|c|}
\hline & M\&E & IE method & Targeting & Sample Size & Time frame & Data collected \\
\hline $\begin{array}{l}\text { Egypt, } \\
\text { Arab } \\
\text { Rep. of }\end{array}$ & Yes & $\begin{array}{l}\text { - Randomization of } \\
\text { matched pairs of firms. } \\
\text { - Matching on a few } \\
\text { characteristics and with } \\
\text { very few firms } \rightarrow \text { control } \\
\text { group could differ in } \\
\text { many unobservables. } \\
\end{array}$ & $\begin{array}{l}\text { - Clear definition of eligibility } \\
\text { rules: Medium and large } \\
\text { exporting firms in greater Cairo. } \\
\text { - Recruitment problems: Very } \\
\text { few firms replied to initial } \\
\text { recruitment } \rightarrow \text { concerns about } \\
\text { selection and external validity. }\end{array}$ & $\begin{array}{l}\text { - No power } \\
\text { calculations and } \\
\text { very small sample } \\
\text { size, particularly } \\
\text { for cluster } \\
\text { corrections. }\end{array}$ & $\begin{array}{l}\text { - Short time to observe } \\
\text { changes in managers' } \\
\text { behavior and workers' } \\
\text { cultural attitudes. }\end{array}$ & $\begin{array}{l}\text { - Quantitative } \\
\text { workers' survey. } \\
\text { - Quantitative firm } \\
\text { survey. }\end{array}$ \\
\hline Kenya & Yes & $\begin{array}{l}\text { Randomization of } \\
\text { matched pairs of villages. }\end{array}$ & & $\begin{array}{l}\text { - No power } \\
\text { calculations. }\end{array}$ & & \\
\hline Liberia & Yes & - Before and after. & - A specific group of producers. & $\begin{array}{l}\text { - No power } \\
\text { calculations. }\end{array}$ & & \\
\hline Mekong & Yes & $\begin{array}{l}\text { Randomization of } \\
\text { matched pairs of villages. }\end{array}$ & $\begin{array}{l}\text { - Three provinces identified } \\
\text { through feasibility study. } \\
\text { - Villages with producer groups } \\
\text { and bamboo traders; but not all } \\
\text { control villages had producer } \\
\text { groups. }\end{array}$ & $\begin{array}{l}\text { - Below the } \\
\text { recommended size } \\
\text { by power } \\
\text { calculations for } \\
\text { clusters } \\
\text { corrections, by } \\
\text { village or producer } \\
\text { groups }\end{array}$ & & $\begin{array}{l}\text { - Household } \\
\text { quantitative data; } \\
\text { FGDs with } \\
\text { producer groups, } \\
\text { IDIs with traders } \\
\text { and village leaders } \\
\text { (or key informants) }\end{array}$ \\
\hline Peru & Yes & $\begin{array}{l}\text { Randomized control trial } \\
\text { of female } \\
\text { microentrepreneurs. }\end{array}$ & & $\begin{array}{l}\text { - Within the } \\
\text { recommended } \\
\text { sample size by } \\
\text { power calculations. }\end{array}$ & $\begin{array}{l}\text { - BDS and TA span } \\
\text { three-month period } \\
\text { each, and about six } \\
\text { months after end-line } \\
\text { data were collected. }\end{array}$ & $\begin{array}{l}\text { - Interviews with } \\
\text { female micro- } \\
\text { entrepreneurs. } \\
\text { - FGD with } \\
\text { beneficiaries. } \\
\text { - IDIs with municipal } \\
\text { officials. }\end{array}$ \\
\hline
\end{tabular}

Source: Authors' compilation. Notes: BDS = business development skills; FGD = focus group discussion; HH = household; IDI = in-depth interviews; TA = technical assistance 
